\title{
Suppression of renal cell proliferation, induction of apoptosis and cell cycle arrest: Cytotoxicity of vanadium in broilers
}

\author{
Xiaodong Liu, Hengmin Cui ${ }^{*}$, Xi Peng, Jing Fang, Wei Cui, Bangyuan Wu \\ Key Laboratory of Animal Diseases and Environmental Hazards of Sichuan Province, College of Veterinary Medicine, Sichuan Ag- \\ ricultural University, Sichuan, China; ${ }^{*}$ Corresponding Author: cui580420@,sicau.edu.cn
}

Received 11 December 2011; revised 30 December 2011; accepted 26 January 2012

\begin{abstract}
The aims of this study were to clarify the effects of high vanadium on the renal cell cycle and apoptosis in broilers. 420 one-day-old avian broilers were divided into six groups and fed on a control diet (vanadium $0.073 \mathrm{mg} / \mathrm{kg}$ ), and five high vanadium diets (vanadium $5 \mathrm{mg} / \mathrm{kg}$, high vanadium group I; 15 mg/kg, high vanadium group II; $30 \mathrm{mg} / \mathrm{kg}$, high vanadium group III; $45 \mathrm{mg} / \mathrm{kg}$, high vanadium group IV; $60 \mathrm{mg} / \mathrm{kg}$, high vanadium group $V$ ) throughout the experimental period of 42 days. As tested by flow cytometry, the percentage of apoptotic renal cells was increased in high vanadium group II, III, IV and V when compared with that of control group. The Proliferating index $(\mathrm{PI})$ of renal cell and the ratio of $\mathrm{S}$, $G_{2}+M$ phase cells were markedly decreased and population of $G_{0} / G_{1}$ cells was increased in high vanadium group II, III, IV and V. The results showed that dietary vanadium in excess of $15 \mathrm{mg} / \mathrm{kg}$ was toxic to kidney by the renal cells cycle arrest and increased apoptosis, which caused the growth depression of the kidney in broilers.
\end{abstract}

Keywords: Dietary High Vanadium; Renal Cells; Apoptosis; Cell Cycle; Flow Cytometry (FCM); Broiler

\section{INTRODUCTION}

Vanadium is an essential trace element for animal species [1] and widely distributed in the environment. Vanadium compounds have been proven to have a great deal of physiological actions, such as insulin-like action [2], intensive inhibition to the Na, K-ATPase [3,4]. At the same time, the toxicity of the vanadium couldn't be neglected. Cytotoxicity induced by vanadium compounds is well do- cumented: in vivo [5,6] and in vitro [7] in both man and animals [8-10], and vanadium can mediated apoptosis and cell cycle arrest in MCF7 cell line [11].

The ammonium metavanadate widely used in chemical industry is a dietary micronutrient and is also a toxic compound which is involved in several cases of enzyme inhibition. Vanadium has been shown to impede the activities of different ATPases [12], protein kinases [13], ribonuclease [14] and phosphatases [15], and to inhibit or stimulate the activity of many DNA or RNA enzymes inducing several genotoxic and mutagenic effects $[16,17]$.

Kidney has quite a closed relationship to vanadium that kidney is the primary organ involved in accumulation of vanadium [18], and its averages about three times higher than for the liver or spleen [19]. The major vanadic excretion pathway is by the kidney and the excretion of vanadium is rapid with a biological half-life of 20 - 40 hours in the urine [20]. At present, there is a few records about the effect or nephrotoxicity caused by vanadium. Vanadium inhibits renal organic ion accumulation and renal $\mathrm{Na}^{+}$, $\mathrm{K}^{+}$-ATPase in vitro and in vivo [21]. The samples of vanadium-rich oil and of this oil products provoked acute proliferative glomerulonephritis, nephrosclerosis and acute intracapillary glomerulonephritis with partial tubular and glomerular necrosis associated with acute renal failure in hybrid mice [22]. Vanadium-induced morphologic changes in the kidney were also more pronounced with age in rats [23].

Therefore, there is a paucity of data regarding the effect of high vanadium on the development of renal cells, especially in the cell cycle of renal cells in broilers. In the present study, the ammonium metavanadate was used to examine the nephrotoxicity of vanadium in broilers by the methods of flow cytometry (FCM) and histochemistry. Our data indicated that dietary high vanadium intake could cause increased apoptosis and cycle arrest of renal cells in broilers. 


\section{MATERIALS AND METHODS}

\subsection{Chickens and Diets}

420 one-day-old healthy avian broilers were divided into six groups of 70 each. There were seven replicates in each group and ten broilers in each replicate. Two of seven replicates in each group were used for the clinical observation during the experiment. Broilers were housed in cages with electrically heated units and were provided with water as well as undermentioned diets ad libitum for 42 days.

The control diet was a corn-soybean basal diet (vanadium $0.073 \mathrm{mg} / \mathrm{kg}$ ) formulated by the US National Research Council (NRC 1994). Ammonium metavanadate was mixed into the corn-soybean basal diet to produce five high vanadium diets $(5 \mathrm{mg} / \mathrm{kg}$, high vanadium group I; $15 \mathrm{mg} / \mathrm{kg}$, high vanadium group II; $30 \mathrm{mg} / \mathrm{kg}$, high vanadium group III; $45 \mathrm{mg} / \mathrm{kg}$, high vanadium group IV; $60 \mathrm{mg} / \mathrm{kg}$, high vanadium group V).

The use of chickens in our experiments was followed and all experimental procedures involving animals were approved by Sichuan Agricultural University Animal Care and Use Committee.

\subsection{Body Weight and Relative Weight of Kidney}

At $7,14,21,28,35$ and 42 days of age during the experiment, five broilers in each group were weighted then euthanized and necropsied. Kidney were dissected from each broiler, and weighed after dissecting connective tissue around the organ. Related weight of kidney was calculated by the following formula:

Related weight $=$ organ weight $(\mathrm{g}) /$ body weight $(\mathrm{kg})$

\subsection{TUNEL Detection}

Detection of DNA fragments in situ using the terminal deoxyribonucleotidyl transferase(TDT)-mediated dUTPdigoxigenin nick end labeling (TUNEL) assay is increasingly applied to investigate cell apoptosis. At 42 days of age, five broilers were human killed and then immediately necropsied. Kidneys were dissected and then were fixed in $4 \%$ paraformaldehyde and routinely processed in paraffin. TUNEL assay was performed in the deparaffinized sections (at a thickness of $4 \mathrm{um}$ ) with an apoptosis Detection Kit (Merck) according to the suppliers' instructions, as described [24]. Briefly, tissue sections were rehydrated in a series of xylene and ethanol solutions and then incubated at room temperature for 20 minutes with Proteinase K (catalog no. JA 1477) in a humidified chamber. Slides were then rinsed in Trisbuffered saline (TBS). The entire specimens were coverd with $3 \% \mathrm{H}_{2} \mathrm{O}_{2}$, and then incubated at room temperature for 5 minutes. Slides were rinsed with TBS. TUNEL enzyme (catalog no. JA 1560) and label solution (catalog no. JA 1559) were mixed and applied to the tissues, which were incubated again in the humidified chamber for $1.5 \mathrm{~h}$ at $37^{\circ} \mathrm{C}$. Slides were rinsed thoroughly in TBS. Stop solution, block solution and conjugate were applied by turns. DAB solution was applied for $15 \mathrm{~min}$ to stain the nuclei of apoptotic cells. The methyl green solution was used to counterstain the nuclei of normal cells. Tissues were dehydrated in a series of three ethanol baths and two xylene baths for 5 min each. The slides were examined on an Olympus light microscope.

\subsection{Annexin-V Apoptosis and Cell Cycle Detection}

Five broilers in each group were humanely killed at 14, 28 , and 42 days of the experiment and kidney were taken from each chicken immediately. As described previously [25], the cell suspension was filtered through a 300-mesh nylon Mesh, washed twice with cold phosphate buffer solution (PH7.4), and then suspended cells in $1 \times$ binding buffer (Cat. No. 51-66121E) at a concentration of $1 \times 10^{6}$ cells $/ \mathrm{mL}$. Transfer $100 \mu \mathrm{L}$ of the solution to a $5 \mathrm{~mL}$ culture tube, and then add $5 \mu \mathrm{L}$ of Annexin V-FITC (Cat. No. 51$65874 \mathrm{X}$ ) and $5 \mu \mathrm{L}$ of PI (Cat. No. 51-66211E). Gently vortex the cells and incubate for $15 \mathrm{~min}$ at reaction temperature $\left(25^{\circ} \mathrm{C}\right)$ in the dark. Add $400 \mu \mathrm{L}$ of $1 \times$ binding buffer to each tube and analyzed by flow cytometry (BD FACSCalibur) within one hour. The percentage of cells in each part of the cell apoptosis was determined by counting $3 \times$ $10^{4}$ cells, using Cell Quest software.

The cell cycle detection was measured by the previously detailed Cui method [26]. The cell suspension at the concentration of $1 \times 10^{6}$ cells $/ \mathrm{mL}$ aforesaid was used for cell cycle detection follow these procedures below: transfer $500 \mu \mathrm{L}$ of the solution to a $5 \mathrm{~mL}$ culture tube and desert supernatant after brachytely centrifuge $(500 \mathrm{rpm})$. Then add $5 \mu \mathrm{L} 0.25 \%$ Tritonx-100 and $5 \mu \mathrm{L}$ PI (Cat. No. 51-6 $6211 \mathrm{E})$. Gently vortex the cells and incubate for $30 \mathrm{~min}$ at reaction temperature $\left(25^{\circ} \mathrm{C}\right)$ in the dark. Finally, add $500 \mu \mathrm{L}$ phosphate buffer solution (PH7.4) to each tube and analyzed by flow cytometry (BD FACSCalibur) within $45 \mathrm{~min}$. The percentage of cells in each stage of the cell cycle was determined by counting $5 \times 10^{4}$ cells, using ModFit LT for Mac V3.0.

\subsection{Statistical Analysis}

Data were subjected to one-way analysis of variance (ANOVA) using SPSS 12.0 for windows and presented as means \pm standard deviation. Differences between means were assessed by Tukey statistical test. A probability value $\leq 0.05$ was considered to be significant.

\section{RESULTS}

\subsection{Changes of Body Weight and Relative Weight of Kidney}

Body weight of broilers were lower in high vanadium 
group III, IV and V $(p<0.01)$ than in control group during the experiment and body weight was lower $(p<0.01)$ in groups II than in control group from 14 days of age to 42 days of age. The body weight was higher $(p<0.05$ or $p<0.01)$ in group I than in control group from 28 days of age to 42 days of age. The results were showed in Table 1.

Relative weight of kidney was significantly higher ( $p$ $<0.01$ ) in high vanadium groups IV and V than in control group during the experiment except 7 days of age and was significantly higher in high vanadium group IV than in control group at 28 days of age. The results were showed in Table 2.

\subsection{Result of TUNEL Detection}

TUNEL detection reveled that apoptotic cells had brownstain nuclei, and had morphologic change of condensed and irregular nuclei. Apoptotic cells were principally distributed within the renal tubule (Figure 1). There were increased frequencies of occurrence in high vanadium groups III, IV and V.

\subsection{Result of Annexin-V Apoptosis and Cell Cycle Detection}

Annexin-V-FITC staining assay by flow cytometry: Annexin V-FITC was used to quantitatively determine the percentages of cells that were actively undergoing apoptosis. Our data suggested that percentages of apoptotic cells in the kidney were significantly increased in high vanadium groups II, III, V and IV when compared with those of control group $(p<0.05$ or $p<0.01)$ at 14,28 , and 42 days of age. The results were shown in Table 3 .

Cell cycle detection by flow cytometry: To examine the dynamics of cell cycle progression, $G_{0} / G_{1}, S$ and $G_{2}+M$ phase distribution of the renal cells in high vanadium group I, II, III, V and IV were compared with those of control group. $\mathrm{G}_{0} / \mathrm{G}_{1}$ phase cell distribution gradually accumulated at 14, 28, and 42 days of age and became significantly increased $(p<0.05$ or $p<0.01)$ in high vanadium group II, III, V and IV. S phase, $\mathrm{G}_{2}+\mathrm{M}$ phase cell distribution and proliferation index (PI) were decreased in the renal cells in high vanadium groups III, IV and V at 14, 28 , and 42 days of age $(p<0.05$ or $p<0.01)$. The results were showed in Table 4.

Table 1. Effect of high vanadium on weight in broilers $(\mathrm{g})$.

\begin{tabular}{|c|c|c|c|c|c|c|}
\hline Groups & 7 days of age & 14 days of age & 21 days of age & 28 days of age & 35 days of age & 42 days of age \\
\hline Control group & $138.58 \pm 13.55$ & $331.32 \pm 26.77$ & $664.04 \pm 65.58$ & $1131.90 \pm 82.67$ & $1716.20 \pm 77.66$ & $2220.29 \pm 99.6$ \\
\hline High vanadium group I & $139.38 \pm 9.99$ & $336.71 \pm 31.25$ & $669.75 \pm 60.32$ & $1174.05 \pm 78.65^{*}$ & $1842.60 \pm 140.2^{* *}$ & $2450.14 \pm 149.34^{* *}$ \\
\hline High vanadium group II & $134.95 \pm 10.7$ & $301.29 \pm 31.23^{* *}$ & $554.00 \pm 52.82^{* *}$ & $961.47 \pm 62.91^{* *}$ & $1508.80 \pm 92.27^{* *}$ & $1970.57 \pm 145.81^{* *}$ \\
\hline High vanadium group III & $126.24 \pm 15.39^{* *}$ & $233.79 \pm 29.49^{* *}$ & $431.25 \pm 79.75^{* *}$ & $767.26 \pm 60.38^{* *}$ & $1176.50 \pm 86.53^{* *}$ & $1436.29 \pm 98.65^{* *}$ \\
\hline High vanadium group IV & $119.42 \pm 16.73^{* *}$ & $178.75 \pm 42.77^{* *}$ & $315.54 \pm 45.17^{* *}$ & $556.11 \pm 50.77^{* *}$ & $901.30 \pm 98.07^{* *}$ & $1242.71 \pm 101.59^{* *}$ \\
\hline High vanadium group V & $90.08 \pm 18.76^{* *}$ & $102.86 \pm 28.27^{* *}$ & $218.17 \pm 39.92^{* *}$ & $358.68 \pm 36.42^{* *}$ & $582.10 \pm 99.19^{* *}$ & $709.43 \pm 52.85^{* *}$ \\
\hline
\end{tabular}

Data are presented with the means \pm standard deviation $(\mathrm{n}=5)$. Compared with the control group, ${ }^{*} p<0.05,{ }^{* *} p<0.01$.

Table 2. Effect of high vanadium on the relative weight ( $\mathrm{g} / \mathrm{kg}$ body weight) of kidney in broilers.

\begin{tabular}{|c|c|c|c|c|c|c|}
\hline Groups & 7 days of age & 14 days of age & 21 days of age & 28 days of age & 35 days of age & 42 days of age \\
\hline Control group & $0.87 \pm 0.13$ & $0.79 \pm 0.08$ & $0.71 \pm 0.09$ & $0.61 \pm 0.07$ & $0.59 \pm 0.06$ & $0.55 \pm 0.04$ \\
\hline High vanadium group I & $0.91 \pm 0.08$ & $0.77 \pm 0.10$ & $0.68 \pm 0.05$ & $0.66 \pm 0.11$ & $0.62 \pm 0.03$ & $0.52 \pm 0.07$ \\
\hline High vanadium group II & $0.95 \pm 0.11$ & $0.82 \pm 0.13$ & $0.71 \pm 0.11$ & $0.60 \pm 0.09$ & $0.64 \pm 0.05$ & $0.56 \pm 0.06$ \\
\hline High vanadium group III & $0.96 \pm 0.06$ & $0.82 \pm 0.08$ & $0.81 \pm 0.04$ & $0.65 \pm 0.10$ & $0.69 \pm 0.07^{* *}$ & $0.59 \pm 0.10$ \\
\hline High vanadium group IV & $0.97 \pm 0.10$ & $0.94 \pm 0.06^{* *}$ & $0.88 \pm 0.10^{* *}$ & $0.78 \pm 0.08^{* *}$ & $0.68 \pm 0.08^{* *}$ & $0.67 \pm 0.09^{* *}$ \\
\hline High vanadium group V & $1.13 \pm 0.09^{* *}$ & $1.67 \pm 0.15^{* *}$ & $1.24 \pm 0.12 * *$ & $0.86 \pm 0.12^{* *}$ & $0.76 \pm 0.07^{* *}$ & $0.71 \pm 0.11^{* *}$ \\
\hline
\end{tabular}

Data are presented with the means \pm standard deviation $(\mathrm{n}=5)$. Compared with the control group, ${ }^{*} p<0.05,{ }^{* *} p<0.01$. 


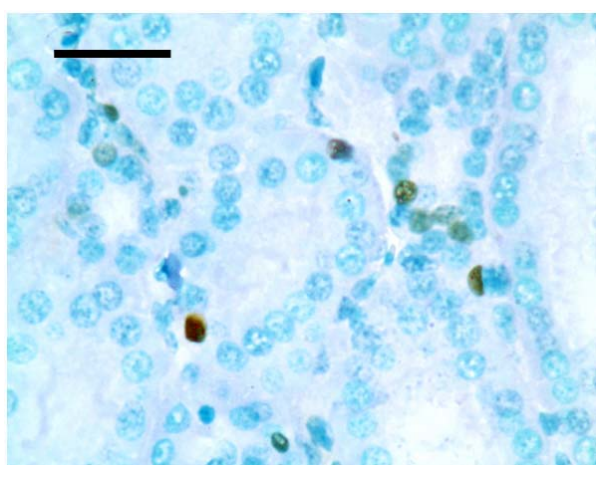

(a)

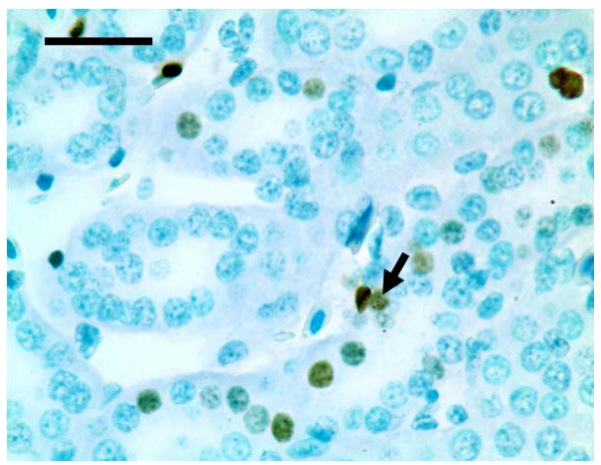

(c)

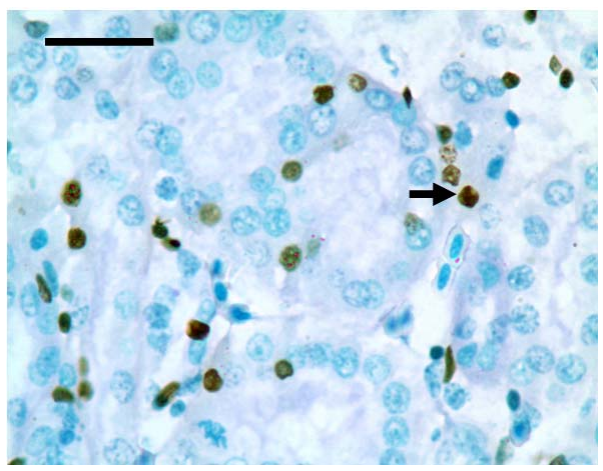

(e)

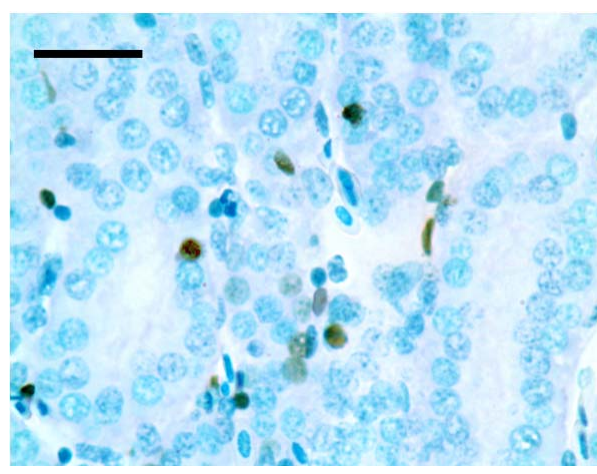

(b)

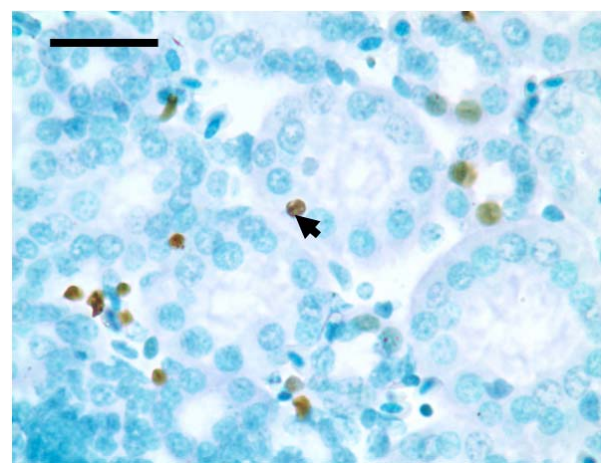

(d)

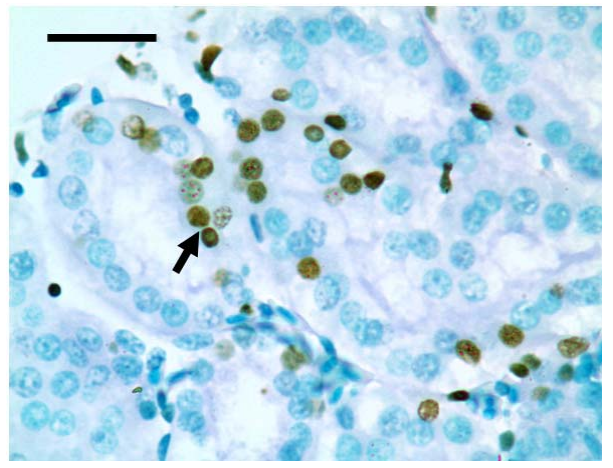

(f)

Figure 1. The population of apoptotic cells are increased in high vanadium groups III (d), IV (e), and V (f) when compared with those of control group (a). The arrows point to the apoptosising cells within the renal tubule, TUNEL $1000 \times$ bars $=19.5 \mu \mathrm{m}$.

Table 3. The percentages of apoptotic renal cells in broilers.

\begin{tabular}{llll}
\hline Groups & 14 days of age & 28 days of age & 42 days of age \\
\hline Control group & $3.06 \pm 0.23$ & $3.28 \pm 0.40$ & $4.05 \pm 0.30$ \\
High vanadium group I & $3.34 \pm 0.44$ & $3.84 \pm 0.37$ & $4.03 \pm 0.18$ \\
High vanadium group II & $4.49 \pm 0.47^{*}$ & $4.47 \pm 0.23^{* *}$ & $4.80 \pm 0.39^{* *}$ \\
High vanadium group III & $4.74 \pm 0.35^{* *}$ & $4.85 \pm 0.58^{* *}$ & $6.04 \pm 0.48^{* *}$ \\
High vanadium group IV & $4.89 \pm 0.21^{* *}$ & $5.33 \pm 0.48^{* *}$ & $7.19 \pm 0.73^{* *}$ \\
High vanadium group V & $5.24 \pm 0.56^{* *}$ & $6.49 \pm 0.72^{* *}$ & $7.56 \pm 0.59^{* *}$ \\
\hline
\end{tabular}

Data are presented with the means \pm standard deviation $(\mathrm{n}=5)$. Compared with the control group, ${ }^{*} p<0.05,{ }^{* *} p<0.01$. 
Table 4. Cycle of the renal cells in broilers (\%).

\begin{tabular}{|c|c|c|c|c|c|c|c|}
\hline Time & Phases & Control group & $\begin{array}{l}\text { High vanadium } \\
\text { group I }\end{array}$ & $\begin{array}{l}\text { High vanadium } \\
\text { group II }\end{array}$ & $\begin{array}{l}\text { High vanadium } \\
\text { group III }\end{array}$ & $\begin{array}{l}\text { High vanadium } \\
\text { group IV }\end{array}$ & $\begin{array}{l}\text { High vanadium } \\
\text { group V }\end{array}$ \\
\hline \multirow{5}{*}{14 days of age } & $\mathrm{G}_{0} / \mathrm{G}_{1}$ & $88.07 \pm 6.36$ & $85.78 \pm 4.23$ & $91.97 \pm 2.07^{* *}$ & $94.42 \pm 1.21^{* *}$ & $97.25 \pm 1.76^{* *}$ & $98.33 \pm 0.32^{* *}$ \\
\hline & S & $6.01 \pm 1.03$ & $6.94 \pm 0.93$ & $3.57 \pm 0.21^{* *}$ & $2.62 \pm 0.51^{* *}$ & $1.18 \pm 0.65^{* *}$ & $0.75 \pm 0.06^{* *}$ \\
\hline & $\mathrm{G}_{2}+\mathrm{M}$ & $5.92 \pm 0.94$ & $6.28 \pm 0.90$ & $4.46 \pm 0.19^{* *}$ & $2.96 \pm 0.71^{* *}$ & $1.57 \pm 1.10^{* *}$ & $0.92 \pm 0.09^{* *}$ \\
\hline & PI & 11.93 & 14.22 & $8.03^{* *}$ & $5.58^{* *}$ & $2.75^{* *}$ & $1.67^{* *}$ \\
\hline & $\mathrm{G}_{0} / \mathrm{G}_{1}$ & $85.85 \pm 3.06$ & $87.07 \pm 5.48$ & $89.46 \pm 0.96^{* *}$ & $90.81 \pm 2.05^{* *}$ & $93.81 \pm 2.43^{* *}$ & $96.63 \pm 0.74^{* *}$ \\
\hline \multirow{3}{*}{28 days of age } & S & $7.43 \pm 1.10$ & $6.32 \pm 1.09$ & $5.11 \pm 0.72^{* *}$ & $4.54 \pm 0.94^{* *}$ & $2.34 \pm 1.24^{* *}$ & $1.32 \pm 0.27^{* *}$ \\
\hline & $\mathrm{G}_{2}+\mathrm{M}$ & $6.72 \pm 0.47$ & $6.61 \pm 0.89$ & $5.43 \pm 0.31$ & $4.65 \pm 1.11^{* *}$ & $3.85 \pm 1.19^{* *}$ & $2.05 \pm 0.17^{* *}$ \\
\hline & PI & 14.15 & 12.93 & $10.54^{*}$ & $9.19^{* *}$ & $6.19^{* *}$ & $3.37^{* *}$ \\
\hline \multirow{4}{*}{42 days of age } & $\mathrm{G}_{0} / \mathrm{G}_{1}$ & $84.95 \pm 1.27$ & $84.08 \pm 0.66$ & $90.49 \pm 0.83^{*}$ & $94.59 \pm 1.90^{* *}$ & $96.42 \pm 0.74^{* *}$ & $97.51 \pm 0.87^{* *}$ \\
\hline & S & $7.61 \pm 0.40$ & $8.21 \pm 0.56$ & $5.01 \pm 0.42^{*}$ & $2.59 \pm 0.15^{* *}$ & $1.57 \pm 0.17^{* *}$ & $1.15 \pm 0.11^{* *}$ \\
\hline & $\mathrm{G}_{2}+\mathrm{M}$ & $7.44 \pm 0.46$ & $7.71 \pm 0.33$ & $4.50 \pm 0.30$ & $2.82 \pm 0.25^{* *}$ & $2.01 \pm 0.19^{* *}$ & $1.34 \pm 0.15^{* *}$ \\
\hline & PI & 15.05 & 15.92 & $9.51^{*}$ & $5.41^{* *}$ & $3.58^{* *}$ & $2.49^{* *}$ \\
\hline \multicolumn{8}{|c|}{$\frac{\mathrm{S}+\left(\mathrm{G}_{2}+\mathrm{M}\right)}{\left./ \mathrm{G}_{1}\right)+\mathrm{S}+\left(\mathrm{G}_{2}+\mathrm{M}\right)} \times 100 \%$} \\
\hline
\end{tabular}

Data are presented with the means \pm standard deviation $(\mathrm{n}=5)$. Compared with the control group, ${ }^{*} p<0.05,{ }^{* *} p<0.01$.

\section{DISCUSSION}

Vanadium is one of the more toxic trace elements. In the natural state, vanadium occurs with positive valencies of two, three, four and five. The greater toxicity has been attributed to compounds in the higher valence states [10]. Ammonium metavanadate which we used with positive valencies of five have more toxicity to the creature. There have been reported that $10 \mathrm{mg} / \mathrm{kg}$ vanadium to the basal diet failed to affect either the growth or mortality of the chicks at six weeks of age, but $25 \mathrm{mg} / \mathrm{kg}$ vanadium significantly depressed growth and increased mortality [27] and $20 \mathrm{mg} / \mathrm{kg}$ added vanadium for the young chick have shown growth depression of $25 \%-30 \%$ with a corn-soybean meal [28]. In the present study, broilers in high vanadium groups III, IV and V showed decreased feed intake and depression. $35.31 \%, 44.03 \%$ and $68.05 \%$ loss of body weight were in group III, IV and V respectively at the end of the experiment. The results of present study indicated that vanadium overdose $15 \mathrm{mg} / \mathrm{kg}$ could inhibit the growth of body and kidney in broilers, which was similar to the results of previous studies. A great quantity of vanadium accumulated (dose-dependently) [29] in the kidney had broken the homeostasis that may be the basic reason for the cytotoxicity. Subcellular distribution studies indicated $90 \%$ accumulation of vanadium in the soluble supernatant fraction at varying stages of cytotoxicity [30]. It was concluded that the multifaceted dependency of vanadium cytotoxicity on its cellular content may have resulted from a cellular balancing between proposed regulatory functions for vanadium and the interactions in- curred with an excessive content.

Apoptosis is a highly regulated process used to eliminate dysplastic or damaged cells from multicellular organisms [31]. Vanadium could induce apoptosis in mice [32], in male germ cells [33] and in T-lymphocyte Jurkat cells [34]. In the present study, by using flow cytometry, the effect of vanadium on cell population classified by annexin V-FITC and PI was examined. The results showed that vanadium greatly increased the population of cells stained with positive annexin $\mathrm{V}$ and negative PI, which represent the increased population of renal cells in early stage of apoptosis. Also, the cells stained with positive annexin $\mathrm{V}$ and PI were increased in the high vanadium groups IV and V, which represent the increased population of renal cells in end-stage apoptosis. By statistically analyzing the sum total of early and end-stage apoptotic renal cells in control group and five high vanadium groups, it was easy to confirm from Table 3 that the populations of apoptotic renal cells were significantly increased in the high vanadium groups II, III, IV and V when compared with those of control group, which was similar to results of TUNEL detection (Figure 1).

It is well known there are two major pathways of apoptosis: the mitochondria-dependent and death receptor-mediated. The mitochondria-dependent pathway mainly caused by DNA damage. The TUNEL detection in our study showed that only cell nucleus was stained in positive. This indicated that the renal apoptosis was partially induced by the mitochondria damage according to the basic principle of the TUNEL detection method for detecting the 
DNA fragmentation. It claimed that vanadium (IV) mediated free radical generation causes 2-deoxyguanosine hydroxylation, which leads to DNA strand breaks [35]. Meanwhile, the vanadium could lead to the mitochondria damage and inhibit mitochondria respiration or inhibited electron transfer chain [36]. It was postulated that significant amounts of vanadate are accumulated in the intermembrane space of liver mitochondria of the exposed rats [37]. The process of "detoxification" by reduction of vanadate in the tissue may be insufficient to prevent the deleterious action of this compound on mitochondria. According to the abovementioned discussion, we should study further the effect of high vanadium on the mitochondria of the renal cells in the further.

Cell cycle regulation is one of the key regulatory mechanisms of cell growth [38]. Many cytotoxic and genetoxic agents arrest the cell cycle at the different phases and then induce apoptotic cell death $[39,40]$. In the present study, obviously increased $\mathrm{G}_{0} / \mathrm{G}_{1}$ renal cell population indicated that the cell cycle of renal cells was arrested at $\mathrm{G}_{0} / \mathrm{G}_{1}$ phase in high vanadium groups II, III, IV and V. At the same time, markedly decreased renal cell population in $\mathrm{S}$ phase, $\mathrm{G}_{2}+\mathrm{M}$ phase and PI (Table 4) value showed that the proliferation of renal cells were greatly inhibited, which were consistent with previous studies in vivo and in vitro [41] and in cancer cells [42]. The cell cycle regulation is much complex and the vanadium induced different phase arrest $[43,44]$.

According to the abovementioned discussion and results in the present study, it is concluded that dietary vanadium in excess of $15 \mathrm{mg} / \mathrm{kg}$ is toxic to kidney by the renal cells cycle arrest and increased apoptosis, which causes the growth depression of the kidney in broilers.

\section{ACKNOWLEDGEMENTS}

The study was supported by the program for Changjiang scholars and innovative research team in university (IRT 0848) and the Education Department (09ZZ017) and Scientific department of Sichuan Province.

\section{REFERENCES}

[1] Hopkins, L.L. and Mohr, H.E. (1974) Proceedings: Vanadiumas an essential nutrient. Federation Proceedings, 33, 1773-1775.

[2] Sekar, N., Li, J. and Shechter, Y. (1996) Vanadium salts as insulin substitutes: Mechanisms of action, a scientific and therapeutic tool in diabetes mellitus research. Critical Reviews in Biochemistry and Molecular Biology, 31, 339359. doi:10.3109/10409239609108721

[3] Cantley, L.C., Josephson, L., Warner, R., Yanagisawa, M., Lechene, C. and Guidotti, G. (1977) Vanadateis a potent $(\mathrm{Na}, \mathrm{K})$ ATPase inhibitor found in ATP derived from muscle. The Journal of Biological Chemistry, 252, 333335.
[4] Grantham, J.J. and Glynn, I.M. (1979) Renal Na, K-ATPase: Determinants of inhibition by vanadium. American Journal of Physiology Renal Physiology, 236, 530-535.

[5] Franke, K.W. and Moxon, A.L. (1937) The toxicity of orally ingested arsenic, selenium, tellurium, vanadium and molybdenum. The Journal of Pharmacology and Experimental Therapeutics, 61, 89-102.

[6] Cortizo, A.M., Bruzzone, L., Molinuevo, S. and Etcheverry, S.B. (2000) A possible role of oxidative stress in the vanadium-induced cytotoxicity in the MC3T3E1 osteoblast and UMR 106 osteosarcoma cell lines. Toxicology, 147, 89-99. doi:10.1016/S0300-483X(00)00181-5

[7] Waters, M.D., Gardner, D.E., Aranyi, C. and Coffin, D.L. (1975) Metal toxicity for rabbit alveolar macrophages in vitro. Environmental Research, 9, 32-47. doi:10.1016/0013-9351(75)90047-X

[8] Sjoberg, S.G. (1950) Vanadium pentoxide dust: A clinical and experimental investigation on its effect after inhalation. British Journal of Industrial Medicine, 7, 195-196.

[9] Stokinger, H.E. (1955) Organic, beryllium and vanadium dusts: A review. AMA. Archives of Industrial Health, 12, 675-677.

[10] Faulkner-Hudson, T.G. (1965) Vanadium: Toxicology and biological significance. British Journal of Industrial Medicine, 22, 163 .

[11] Rajarshi, S.R., Rana, B., Swami, B., Venu, V. and Chatterjee, M. (2006) Vanadium mediated apoptosis and cell cycle arrest in MCF7 cell line. Chemico-Biological Interactions, 163, 239-247. doi:10.1016/j.cbi.2006.08.006

[12] Sabbioni, E., Pozzi, G., Pintar, A., Cassella, L. and Garattini, S. (1991) Cellular retention cytotoxicity and morphological transformation by vanadium (IV) and vanadium (V) in BALB/3T3 cell lines. Carcinogenesis, 12, 47-52. doi:10.1093/carcin/12.1.47

[13] Stankiewicz, P.J. and Tracey, A.S. (1995) Stimulation of enzyme activity by oxovanadium complexes. Metal Ions Biological Systems, 31, 249-285.

[14] Lau, J.Y., Qian, K.P., Wu, P.C. and Davis, G.L. (1993) Ribonucleotide vanadyl complexes inhibit polymerase chain reaction. Nucleic Acids Research, 21, 2777. doi:10.1093/nar/21.11.2777

[15] Tracey, A.S. (2000) Hydrooxamido vanadates, aqueous chemistry and function in protein tyrosine phosphatases and cell cultures. Journal of Inorganic Biochemistry, 80, 11-16. doi:10.1016/S0162-0134(00)00033-7

[16] Stemmler, A.J. and Burrows, C.J. (2001) Guanine versus deoxyribose damage in DNA oxidation mediated by vanadium (IV) and vanadium(V) complexes. Journal of Inorganic Biochemistry, 6, 100-106.

[17] Altamirano-Lozano, M., Alvarez-Barrera, L., Valverde, M. and Rojas, E. (1996) Reprotoxic and genotoxic studies of vanadium pentoxide in male mice. Teratogenesis Carcinogenesis and Mutagenesis, 16, 7-17. doi:10.1002/(SICI)1520-6866(1996)16:1<7::AID-TCM2 33.0.CO;2-M

[18] John, N., Hathcock, C.H. and Hill, G. (1964) Vanadium toxicity and distribution in chicks and rats. The Journal of Nutrition, 82, 106-110. 
[19] Ramandham, S., Heyliger, C. and Gresser, M.J. (1991) The distribution and half-life for retention of vanadium in the organs of normal and diabetic rats orally fed vanadium (IV) and vanadium (V). Biological Trace Element Research, 30, 119-124. doi:10.1007/BF02990348

[20] Barceloux, D.G. and Barceloux, D. (1999) Vanadium. Clinical Toxicology, 37, 265-278. doi:10.1081/CLT-100102425

[21] Phillips, T.D., Nechay, B.R. and Heidelbaugh, N.D. (1983) Vanadium: Chemistry and the kidney. Federation Proceedings, 42, 2969-2973.

[22] Sarsebekov, E.K., Dzharbusynov, B.U. and Doskeeva, R.A. (1994) The nephrotoxic action of heavy crude with a high vanadium content and of its refinery products. Urol Nefrol (Mosk), 35-36.

[23] Torre, A., Granero, S., Mayayo, E., Corbella, J. and Domingo, J.L. (1999) Effect of age on vanadium nephrotoxicity in rats. Toxicology Letters, 105, 75-82. doi:10.1016/S0378-4274(98)00385-3

[24] Peng, X., Cui, Y., Cui, H.M., Cui, W. and Deng, J.L. (2009) The decrease of relative weight, lesions, and apoptosis of bursa of Fabricius induced by excess dietary selenium in chickens. Biological Trace Element Research, 131, 33-42. doi:10.1007/s12011-009-8345-6

[25] Chen, T., Cui, Y., Gong, T., Bai, C.M., Peng, X. and Cui, H.M. (2009) Inhibition of splenocyte proliferation and spleen growth in young chickens fed high fluoride diets. Fluoride, 42, 203-209.

[26] Cui, H.M., Fang, J. and Peng, X. (2003) Pathology of the thyums, spleen and bursa of Fabricius in zinc-deficient ducklings. Avian Pahology, 32, 259-263. doi:10.1080/10307945031000097840

[27] Hathcock, J.N., Hill, C.H. and Matrone, G. (1964) Vanadium toxicity and distribution in chicks and rats. The Journal of Nutrition, 82, 106-110.

[28] Berg, L.R. (1966) Effect of diet composition on vanadium toxicity for the chick. Poultry Science, 45, 1346-1352.

[29] Domingo, J.L., Llobet, J.M. and Tomas, J.M. (1985) Short-term toxicity studies of vanadium in rats. Journal of Applied Toxicology, 5, 418-421. doi:10.1002/jat.2550050616

[30] Bracken, W.M., Sharma, R.P. and Elsne, Y.Y. (1985) Vanadium accumulation and subcellular distribution in relation to vanadate induced cytotoxicity in vitro. Cell Biology and Toxicology, 1, 259-268. doi:10.1007/BF00118191

[31] King, K.L. and Cidlowski, J.A. (2004) Cell cycle and apoptosis: Common pathways to life and death. Journal of Cellular Biochemistry, 58, 175-180. doi:10.1002/jcb.240580206

[32] Wang, L., Medan, D. and Mercer, R. (2003) Vanadiuminduced apoptosis and pulmonary inflammation in mice: role of reactive oxygen species. Journal of Cellular Physiology, 195, 99-107. doi:10.1002/jep.10232

[33] Aragon, M.A., Ayala, M.E., Fortoul, T.I., Bizarro, P. and Altamirano-Lozano, M. (2005) Vanadium induced ultrastructural changes and apoptosis in male germ cells. Re- productive Toxicology, 20, 127-134.

[34] Ye, J., Ding, M., Leonard, S.S., Robinson, V.A., Millecchia, L., Zhang, X.Y., Castranova, V., Vallyathan, V. and Shi, X.L. (1999) Vanadate induces apoptosis in epidermal JB6 plus cells via hydrogen peroxide-mediated reactions. Molecular and Cellular Biochemistry, 202, 9-17. doi:10.1023/A:1007078915585

[35] Shi, X.L., Jiang, H.G., Mao, Y., Ye, J.P. and Saffiotti, U. (1996) Vanadium (IV)-mediated free radical generation and related 2'-deoxyguanosine hydroxylation and DNA damage. Toxicology, 106, 27-38. doi:10.1016/0300-483X(95)03151-5

[36] Byczkowski, J., Zychliński, L. and Tłuczkiewicz, J. (1979) Interaction of vanadate with respiratory chain of rat liver and wheat seedling mitochondria. International Journal of Biochemistry, 10, 1007-1011. doi:10.1016/0020-711X(79)90081-8

[37] Zychlinski, L. and Byczkowski, J.Z. (1990) Inhibitory effects of vanadium pentoxide on respiration of rat liver mitochondria. Archives Environmental Contamination Toxicology, 19, 138-142. doi:10.1007/BF01059822

[38] Murray, A.W. (2004) Recycling the cell cycle: Cyclins revisited. Cell, 116, 221-234. doi:10.1016/S0092-8674(03)01080-8

[39] Fujimoto, K., Hosotani, R., Doi, R., Wada, M., Lee, J.U., Koshiba, T., Miyamoto, Y., Tsuji, S., Nakajima, S. and Imamura, M. (1999) Induction of cell cycle arrest and apoptosis by a novel retinobenzoic-acid derivative, TAC101 , in human pancreatic-cancer cells. International Journal of Cancer, 81,637-644.

doi:10.1002/(SICI)1097-0215(19990517)81:4<637::AIDIJC21>3.0.CO;2-4

[40] Gamet-Payrastre, L., Li, P., Lumeau, S., Cassar, G., Dupont, M.A., Chevolleau, S., Gasc, N., Tulliez, J. and Terce, F. (2000) Sulforaphane, a naturally occurring isothiocyanate, induces cell cycle arrest and apoptosis in HT29 human colon cancer cells. Cancer Research, 60, 14261433.

[41] Ray, R.S., Ghosh, B. and Rana, A. (2007) Suppression of cell proliferation, induction of apoptosis and cell cycle arrest: Chemopreventive activity of vanadium in vivo and in vitro. International Journal of Cancer, 120, 13-23. doi:10.1002/ijc.22277

[42] Evangelou, A.M. (2002) Vanadium in cancer treatment. Critical Reviews in Oncology Hematology, 42, 249-265. doi:10.1016/S1040-8428(01)00221-9

[43] Fu, Y., Wang, Q., Yang, X.G. and Yang, X.D. (2008) Vanadyl bisacetylacetonate induced G1/S cell cycle arrest via high-intensity ERK phosphorylation in HepG2 cells. Journal of Biological Inorganic Chemistry, 13, 10011009. doi:10.1007/s00775-008-0387-2

[44] Zhang, Z., Leonard, S.S. and Huang, C. (2003) Role of reactive oxygen species and MAPKs in vanadate-induced G2/M phase arrest. Free Radical Biology \& Medicine, 34, 1333-1342. doi:10.1016/S0891-5849(03)00145-X 